\title{
Factors Affecting Consumer Buying Behavior For Electronic Notebook
}

\author{
Muhammad Arsalan Khan, Muhammad Abdullah Idrees, and Ayesha Khan
}

\begin{abstract}
The purpose of this thesis is to analyze the factors affecting consumer buying behavior for electronic notebook in Pakistan. The vast formulation that has taken place in IT sector followed by many rivals and acquisitions in the market place, lead both practitioners and students to concentrate on the consumer buying behavior and decision making in notebook industry. NDP Group report published in 2003 national computer has, that US was making more money by selling laptops then selling desktop computers. This was the first time US outdated desktop personal computers to the revolutionary notebooks. This research will explain the factors influencing the buying behavior of electronic notebooks. What makes this study different from other is that it discusses the many factors affecting while a consumer is making a notebook purchase. It is found that core technical specifications, band image, price and connectivity, fashion and trends, physical appearance, value function and technology, and remote are the few factors that affect consumers' notebook purchases.
\end{abstract}

Index Terms-Advertising; Brand Loyalty; Consumer Buying Behavior; Fashion; Price; Technology.

\section{INTRODUCTION}

\section{A. Overview}

It was only a couple of years ago that the concept of portable computers came into being and changed the way we think or use computers [6]. It made it possible for work or leisure to be conducted literally anywhere, be it in a plane, at work, at school and even more specific applications like construction sites etc. However, the rapid development of technology has led to an influx of brands and models of notebook that has made the purchase process much more difficult as consumers are spoilt by choice [3]. This has led to consumer confusion in the notebook market. For manufactures it is a big problem when a customer is confuse as it leads to loss of sales and weakened brand loyalty [7]. We conducted a set of interviews along with other research methods to understand what causes confusion in the notebook market and what consumer buying behavior strategies are applied by consumers. This information can help manufacturers better market their products and reduce confusion for consumers to streamline their buying experience and in turn develop a loyal customer base. The rapid decline in computer prices could be the result of a variety of forces. Process innovation, falling input costs, inter-temporal price discrimination, and competition are the explanations that may be relevant for the retail computer industry. Brand extension is a widely adopted strategy that enables firms to take advantage of existing brand equity and enter a new product category [9].

Published on June 18, 2020.
With the increased volume of financial risk and product promotion cost of introducing new electronic gadgets, several firms have transformed their strategies for capitalization of the goodwill linked with present brand names by launching extensions. However, the possibility of negative impacts on the parent brand is a concern for marketers during this process $[7,10]$. Despite this fact, more and more firms are utilizing extensions and counterextensions across different product categories to enhance their market share, and/or to preserve it. This practice has been applied in domestic and international package delivery, pitcher-based and faucet-mounted water filtration, consumer electronics and computer hardware [7]. In a highly dynamic market environment, firms have to sell higher quality products at prices lower than their competitors, or else they may drop out of the market if their brand is not the first or second in that particular market [5]. Product differentiation plays a key role in gaining competitive advantage and, in order for such differentiation to occur, a firm must have the technological capability to build new products more efficiently [2].

\section{B. Problem Statement}

The research was focused on examining factors that affect consumer decision making for purchase of electronic notebook.

\section{Hypotheses}

H1: Fashion and trend have a significant impact on consumer behavior for buying for electronic notebook.

$\mathrm{H} 2$ : Price has a significant impact on consumer buying behavior for buying for electronic notebook.

H3: Technology has a significant impact on consumer buying behavior for buying for electronic notebook.

H4: Brand loyalty has a significant impact on consumer buying behavior for buying for electronic notebook.

H5: Various brands and specifications have a significant impact on consumer buying behavior for buying for electronic notebook.

H6: Specification has a significant impact on consumer buying behavior for buying for electronic notebook.

H7: Retailer's dealer's influence has a significant impact on consumer buying behavior for buying for electronic notebook.

H8: Advertising has a significant impact on consumer buying behavior for buying for electronic notebook.

\section{Outline of the Study}

In chapter 1 , an overview of the research study is carried out, the proposed hypotheses and the problem statement as to why the study is being carried out. The second chapter provides an extensive literature review of the phenomenon 
being studied which has been lent from the earlier researches to provide credibility to the research. Chapter 3 explains the primary and secondary sources from which data was collected, the tool used for collecting the data, the sample size used for the statistical analysis, the statistical technique applied to it and the conceptual and statistical model developed. Chapter 4 displays the results and interpretations of the statistical analysis and the assessment summary of the hypothesis that have been tested. Chapter 5 comprises of a discussion on the research, a conclusion for the study, the implications of the research and some recommendations that the study suggests.

\section{LITERATURE REVIEW}

The consumer must be better than the product of another brand or company, and understanding the causes of this election is very important for sales of existing products more efficiently than its competitors [13]. Demographic profile of consumers determines their perception of purchase, their relation to products or brands in order to influence their buying decisions. $\{5\}$ found many factors that the consumer purchase of e-commerce solution to identify the influence: understanding the product, shopping, housing and customer risk to consumers.

[30 distinguish five stages in the decision to buy: First determine whether to formulate something missing laptop, (2) or determine which devices to buy new or changed, 3) the choice of technology, 4) suppliers' selection 5) Permission to purchase and a license to commit the required funds. The researchers concluded that the housing and on a logical analysis of the decision to follow. [11], suggest that consumer behavior is "the study of the processes involved when individuals or groups select, purchase, use, experience and take advantage of the product in order to satisfy the customer desire and expectations" and that consumer hyperchoice is "a condition where a large number of options available leads us to a second choice and can drain mental energy, reducing our ability to make important decisions". [1] stated that consumer confusion can also occur due to conflicting information, insufficient information and mistaken identity.

The common frameworks used to understand and evaluate hyper-choice and consumer behaviour are mostly decision related assessments as consumers often follow a common decision-making steps.

The continuum is a helpful way to understand the consumer decision process. According to [11], consumer researchers think in terms of a continuum, which consists of extended problem solving on one hand and habitual decision making on the other end many decisions fall in the middle and are categorized as limited problem solving. Below is a table explaining the different aspects comprehensive and incomprehensive problem solving

The Continuum of buying decision behaviour is shown below:
TABLE 2.1

\begin{tabular}{|c|c|c|}
\hline $\begin{array}{l}\text { Everyday } \\
\text { Behavior }\end{array}$ & $\begin{array}{l}\text { Figure out } \\
\text { Problem }\end{array}$ & $\begin{array}{l}\text { Comprehensively } \\
\text { Figuring out Problem }\end{array}$ \\
\hline $\begin{array}{l}\text { Low Product } \\
\text { Costs }\end{array}$ & & Expensive product cost \\
\hline $\begin{array}{l}\text { Regular } \\
\text { Purchasing }\end{array}$ & & Irregular Purchasing \\
\hline $\begin{array}{l}\text { Low involvement } \\
\text { of customer }\end{array}$ & & $\begin{array}{l}\text { High involvement of } \\
\text { customer }\end{array}$ \\
\hline $\begin{array}{l}\text { Well-known } \\
\text { Brand Image }\end{array}$ & & Unfamiliar Brand Image \\
\hline $\begin{array}{l}\text { Less time thought } \\
\text { and information } \\
\text { towards purchase }\end{array}$ & & $\begin{array}{l}\text { More time, thought and } \\
\text { information towards } \\
\text { purchase }\end{array}$ \\
\hline
\end{tabular}

TABLE 2.2

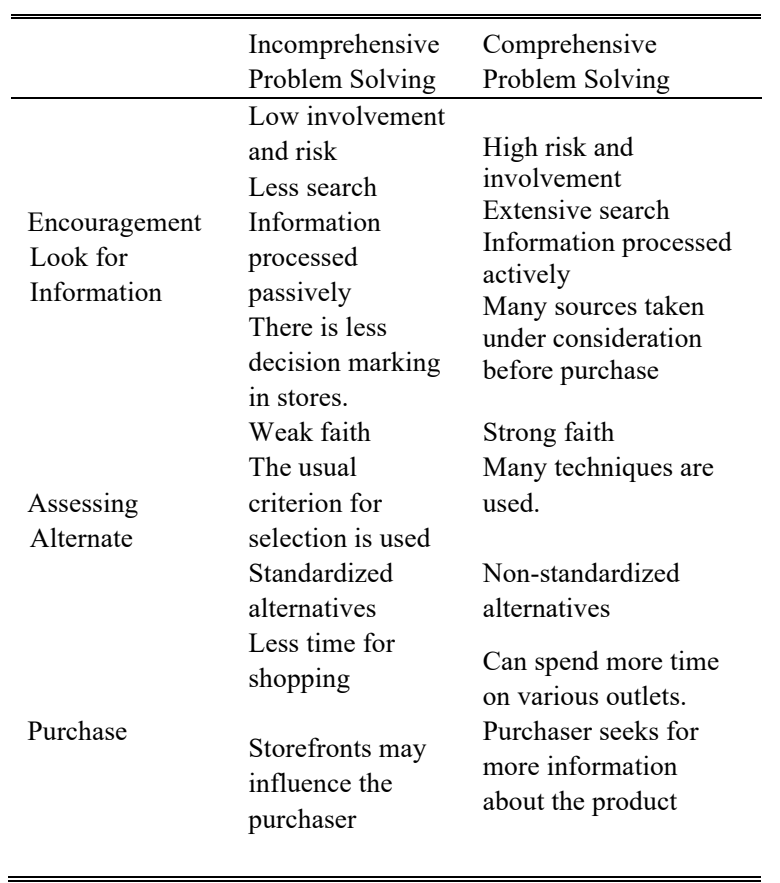

[11], also states that the extended problem solving is related to traditional decision-making and limited problem solving is usually simple and straight forward compared to extensive problem solving. Now we are going to link brand or company loyalty to one aspect of the above discussed framework. [1], state that consumers' expectation about the product they purchase and also about the retailer they purchase it from. The satisfaction that they experience from this habitual decision making will exceed level of expected satisfaction often resulting in loyalty to the product or the retailer. Consumers tend to reward brands or companies by continued purchase and this behaviour is highly resistant to change. [1], suggest that knowledge is the information stored in consumers' memory about products. It is also a very broad pool that divides customers' knowledge about a certain product. Sources can be divided into two major dimensions which are personal, impersonal and businesscontrolled and non-business controlled [1]. The below shows main sources divided within the two dimensions: 
TABLE 2.3

\begin{tabular}{|c|c|c|}
\hline & $\begin{array}{l}\text { BUSINESS } \\
\text { CONTROLLED }\end{array}$ & $\begin{array}{l}\text { NON-BUSINESS } \\
\text { CONTROLLED }\end{array}$ \\
\hline PERSONAL & $\begin{array}{l}\text { Sales personnel } \\
\text { Service } \\
\text { personnel } \\
\text { Paid product } \\
\text { endorsers }\end{array}$ & $\begin{array}{l}\text { Family and friends } \\
\text { Co-workers } \\
\text { Other shoppers } \\
\text { Influential } \\
\text { internet forums and } \\
\text { bulletin boards and } \\
\text { expert opinion leaders }\end{array}$ \\
\hline IMPERSONAL & $\begin{array}{l}\text { Products } \\
\text { Point-of- } \\
\text { purchase } \\
\text { materials } \\
\text { (e.g. displays, } \\
\text { store signage, } \\
\text { advertising } \\
\text { circulars) } \\
\text { Advertising } \\
\text { Catalogues } \\
\text { Corporate } \\
\text { websites } \\
\text { Yellow Pages }\end{array}$ & $\begin{array}{l}\text { Radio show and } \\
\text { Televisions } \\
\text { Non Corporate } \\
\text { websites } \\
\text { (e.g. blogs, } \\
\text { government sites) } \\
\text { Books } \\
\text { Government reports } \\
\text { Newspapers } \\
\text { Magazines }\end{array}$ \\
\hline
\end{tabular}

Sources of information determine the perspective of buyers to large extent. However if all the facts pull towards a different direction a confusion might take place. [7], suggested that the confusion is due to the excessive stimulus, stimulus similarity conflicting or misleading, and vague or incomplete information. Now we will look at evaluating criteria. Evaluating measurement criteria used to assess merits of the options. Another important point in criteria is the extent to which products differ from one another eventually carrying more or less weight in the decision making process [4]. They defines determinant attributes as "the features we actually use to differentiate among our choices while choosing technological products. Now we will look at the methodology used to conduct our research on customer buying behaviour in the notebook industry. Similarity between the products is very high, as are many manufacturing even the technical aspects of notebooks by companies the same Intel processors with confusion consumer with increased similarity physical increase, and the introduction of "I, too" products become more problematic when it comes to buying process and notebook manufacturers use factors such as brand image and physical appearance of a laptop computer to distinguish products. Regarding respondents said that after the price and reliability of the signs of the main sources of confusion about which notebook to choose comes to color, design and appearance [12].

In this regard, Apple has managed to create a fashion statement with laptops of their own, which can say the most attractive option in the search for answers and the size of the interview support this argument. The exception are Apple's products, which have less frequent product introductions, roughly constant prices over their product cycle, and consumers with high and narrow income distributions. One respondent stated that this uses a Mac, because it is a "rage today." The arrival of laptops of various brands attractive, as well as many of the new entrants to the market to more confusion in the industry.

Another point to note is that since buying a laptop is rare, and lack of knowledge of consumers shopping experience and is an obstacle to deal with information overload and makes it difficult to narrow down the choices. In this paper, a laptop is something that you buy once every few years or so, we have learned from the desk research and interviews while the importance is very important for its reliability, especially in terms of after-sales service. We can learn from the answers that the views of consumers receive the service plays an important role because they have the peace of mind that if there is any mistake will be covered. Said one respondent: "If you were to buy a laptop would buy a brand certainly I know ... but certainly regardless of what is being extended warranty my country to the fullest extent, because access to the lemon these days is very high."

\section{RESEARCH METHODS}

\section{A. Method of Data Collection}

First Stage: For the first stage of research i searched journal articles and reviews from various sources to get a better understanding of the situation in the notebook market. Second Stage Since this study focused on factors affecting the decision to buy the laptop users, it was clearly appropriate to the traditional online research survey to be carried out. According to the research objectives of this study, a questionnaire was prepared and has been shown in social media such as Facebook and LinkedIn and the questionnaire was filled with people, mostly students, in different places such as malls, universities and electronic bazaar.

\section{B. Sampling Technique:}

Convenience sampling - a non-probability method - was used to perform sampling.

\section{Sample Size}

A sample size of 150 respondents was approached for collection of data.

\section{Instrument of Data Collection}

A questionnaire containing structured questions was applied as the instrument for collection of primary data.

\section{E. Reliability}

Here in the table given below the value of Cronbach's Alpha is 0.588 which show the reliability in data.

TABLE 3.1: RELIABILITY TEST

\begin{tabular}{lll}
\hline Cronbach's Alpha & $\begin{array}{l}\text { Cronbach's Alpha Based } \\
\text { on Standardized Items }\end{array}$ & N of Items \\
\hline .558 & .622 & 8 \\
\hline \hline
\end{tabular}




\section{F. Research Model Developed}

Fig 3.1

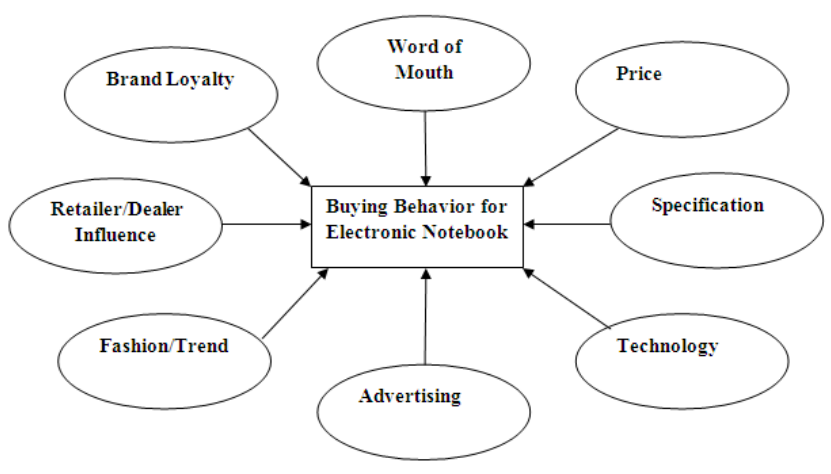

\section{G. $\quad$ Statistical Test Used}

One Sample Test is the technique used for data analysis.

\section{Results AND FINDINGS}

In this chapter, we have analyzed the statistical results and their interpretation according to the research hypotheses. There are eight research hypotheses in the current study their empirical conclusion is explained in this chapter.

\section{A. Findings and Interpretation of the results}

TABLE 4.1: CASE PROCESSING SUMMARY

\begin{tabular}{llll}
\hline \hline & & $\mathrm{N}$ & $\%$ \\
\hline Cases & Valid & 150 & $100 \%$ \\
& Excluded & 0 & 0 \\
& Total & 150 & $100 \%$ \\
& & & \\
\hline \hline
\end{tabular}

The above table explains the total no of sample size that is used in the research for the analysis. For concluding the results the sample size selected for analysis was 150 i.e $(\mathrm{N}=150)$.

TABLE 4.2: ONE-SAMPLE STATISTICS

\begin{tabular}{lccll}
\hline \hline & $\mathrm{N}$ & Mean & $\begin{array}{l}\text { Std. } \\
\text { Deviation }\end{array}$ & $\begin{array}{l}\text { Std. Error } \\
\text { Mean }\end{array}$ \\
\hline Brand Loyalty & 150 & 3.86 & 1.093 & .089 \\
Word of Mouth & 150 & 3.25 & 1.135 & .093 \\
Specifications & 150 & 4.09 & 1.045 & .085 \\
Price & 150 & 3.71 & 1.200 & .098 \\
Technology & 150 & 4.34 & .954 & .078 \\
Fashion and Trends & 150 & 3.55 & 1.213 & .099 \\
Retailers, Dealers & 150 & 2.94 & 1.031 & .084 \\
Influence & 150 & 3.13 & 1.107 & .090 \\
Advertising & & & & \\
\hline \hline
\end{tabular}

From the above table it is possible to put forward the following hypotheses:

H1 accepted: Brand loyalty mean value is 3.86 that show brand loyalty has an impact on consumer buying behavior for ENB's.

$\mathrm{H} 2$ rejected: Word of mouth has mean value of 3.25 that shows word of mouth has no significant impact on consumer buying behavior for ENB's.

H3 accepted: Specifications mean value is 4.09 that shows specification has a significant impact on consumer buying behavior for ENB's.

H4 rejected: Price mean value is 3.071 that show that Price has not a significant impact on consumer buying behavior for ENB's.

H5 accepted: Technology mean value is 4.34 that show that technology has a significant impact on consumer buying behavior for ENB's.

H6 rejected: Fashion trends mean value is 3.55 that show that fashion trends has not a significant impact on consumer buying behavior for ENB's.

H7 rejected: retailer dealer influence mean value is 2.94 that show retailer and dealer influence has not a significant impact on consumer buying behavior for ENB's.

H8 rejected: Advertising mean value is 3.13 that show advertising has not a significant impact on consumer buying behavior for ENB's.

TABLE 4.3: ONE-SAMPLE TEST

\begin{tabular}{|c|c|c|c|c|c|c|}
\hline & \multicolumn{6}{|c|}{ Test Value $=4$} \\
\hline & \multirow[b]{2}{*}{$\mathrm{T}$} & \multirow[b]{2}{*}{$\mathrm{dF}$} & \multirow[b]{2}{*}{$\begin{array}{l}\text { Sig. (2- } \\
\text { tailed) }\end{array}$} & \multirow[b]{2}{*}{$\begin{array}{l}\text { Mean } \\
\text { Difference }\end{array}$} & \multicolumn{2}{|c|}{$\begin{array}{l}95 \% \text { Confidence } \\
\text { Interval of the } \\
\text { Difference }\end{array}$} \\
\hline & & & & & Lower & Upper \\
\hline Brand Loyalty & $\begin{array}{l}- \\
1.568\end{array}$ & 149 & .119 & -.140 & -.32 & .04 \\
\hline Word of Mouth & -8.131 & 149 & .000 & -.753 & -.94 & -.57 \\
\hline Specifications & 1.094 & 149 & .276 & -.093 & -.08 & .26 \\
\hline Price & -2.925 & 149 & .004 & -.287 & -.48 & -.09 \\
\hline Technology & 4.364 & 149 & .000 & -.340 & -.19 & .49 \\
\hline $\begin{array}{l}\text { Fashion and } \\
\text { Trends }\end{array}$ & -4.578 & 149 & .000 & -.453 & -.65 & -.26 \\
\hline $\begin{array}{l}\text { Retailers, Dealers } \\
\text { Influence }\end{array}$ & $\begin{array}{l}- \\
12.58 \\
9\end{array}$ & 149 & .000 & -1.060 & -1.23 & -.89 \\
\hline Advertising & -9.662 & 149 & .000 & -.873 & -1.05 & -.69 \\
\hline
\end{tabular}

Brand loyalty, specifications and technology mean values are greater than or close to test value 4 that shows the importance of these variables in customer decision making for purchase of electronic notebook. 


\section{B. Hypotheses Assessment Summary}

\begin{tabular}{|c|c|c|c|}
\hline No. & Hypothesis & Sig Value & Empirical C \\
\hline $\mathrm{H}_{1}$ & $\begin{array}{l}\text { Fashion and trend have a } \\
\text { significant impact on } \\
\text { consumer behavior for buying } \\
\text { for electronic notebook }\end{array}$ & .119 & Accepted \\
\hline $\mathrm{H}_{2}$ & $\begin{array}{l}\text { Price has a significant impact } \\
\text { on consumer buying behavior } \\
\text { for buying for electronic } \\
\text { notebook }\end{array}$ & .000 & Rejected \\
\hline $\mathrm{H}_{3}$ & $\begin{array}{l}\text { Technology has a significant } \\
\text { impact on consumer buying } \\
\text { behavior for buying for } \\
\text { electronic notebook }\end{array}$ & .276 & Accepted \\
\hline $\mathrm{H}_{4}$ & $\begin{array}{l}\text { Brand loyalty has a } \\
\text { significant impact on } \\
\text { consumer buying behavior for } \\
\text { buying for electronic } \\
\text { notebook }\end{array}$ & .004 & Rejected \\
\hline $\mathrm{H}_{5}$ & $\begin{array}{l}\text { Various brands and } \\
\text { specifications have a } \\
\text { significant impact on } \\
\text { consumer buying behavior for } \\
\text { buying for electronic } \\
\text { notebook }\end{array}$ & .000 & Accepted \\
\hline $\mathrm{H}_{6}$ & $\begin{array}{l}\text { Specification has a significant } \\
\text { impact on consumer buying } \\
\text { behavior for buying for } \\
\text { electronic notebook }\end{array}$ & .000 & Rejected \\
\hline $\mathrm{H}_{7}$ & $\begin{array}{l}\text { Retailer's dealer's influence } \\
\text { has a significant impact on } \\
\text { consumer buying behavior for } \\
\text { buying for electronic } \\
\text { notebook }\end{array}$ & .000 & Rejected \\
\hline $\mathrm{H}_{8}$ & $\begin{array}{l}\text { Advertising has a significant } \\
\text { impact on consumer buying } \\
\text { behavior for buying for } \\
\text { electronic notebook }\end{array}$ & .000 & Rejected \\
\hline
\end{tabular}

\section{CONCLUSION, Discussions, IMPLICATIONS, LimitaTION AND FUTURE RESEARCH}

\section{A. Conclusion}

In the lives of today's hectic and modern, we are over loaded with information on the products and services that we use, and faced a series of alternatives and options for us to spend our money on and also large variety of high promotions and "special offers". Lots of authors are confused about this behavior. Hence, towards the climax, in order for marketers to gain a competitive advantage edge in the notebook industry, they need to create a list of factors affecting consumer buying behavior explaining where and to what extent is the confusion present in the industry. After analyzing the causes, manufacturers, marketers and retailers will have a more lucid market view enabling them to take relative actions to reduce confusion in purchase decision of the buyer. Hence, this will eventually lead to re-evaluation of brand choice.

\section{B. Discussion}

The study was aimed to analyze the factors affecting consumer buying behavior for electronic notebook in Pakistan. Many factors were considered in this research to know the impact of consumer buying behavior for electronic notebook, core technical specifications, band image, price and connectivity, fashion and trends, physical appearance, value function and technology, and remote are the few factors that affect consumers' notebook purchases. To know the factors that affect consumer buying behavior for electronic notebook a questionnaire was prepared data was collected from many students and other people that use laptops. Results showed that brand loyalty, specification and technology are the most important factors that affect consumer buying behavior for electronic notebook.

\section{Implications}

This section is concerned with analyzing the factors affecting consumer buying behavior strategies used in the notebook market. This information can be used by manufacturers in order to reduce confusion of buying decision around their products to make their purchase process as simple as possible for consumers and to gain a competitive advantage over their competitors. Referring back to [11] continuum of buying decision behaviour we can say that generally consumer decision making when it comes to purchasing a notebook falls more towards extensive problem solving. This is because Laptop's are expensive products as well as infrequent purchases. However, with reference to other stages of the continuum, questionnaire responses show that when it comes to product class and brand consumers are more likely to follow routine response behaviour and opt for more well-known, established and familiar brands [11]. However, the amount of time given to research in order to clarify purchasing goals or reduce confusion varies from person to person. Our sample consisted of university students, people from shopping malls etc who are more likely to be involved in the buying process; however it must be noted that elderly adults tend to satisfy their selves more instead of more search and compared to adults the young people search more than elderly adults [2].

\section{Future Research}

The future research may include many other factors which are important to be considered for buying an electronic notebook like processor speed and type, display resolution quality, after sales service, repair maintenance, DVD player etc. For further research some specific brands of laptops for example HP, Dell, Toshiba and HCL are also considered to know that which brand is more popular and which is least popular for buyers of electronic notebook.

\section{REFERENCES}

[1] Blackwell R D, Miniard P W \& Engel J F, (2006), Consumer Behavior, Dryden Press International Edition, Fort Worth (10th ed.)

[2] Cole, C.A. \& Balasabramanian, S.K. (1993), "Age differences in consumers' search for information: public policy implications", Journal of Consumer Research, Vol. 20, June, pp. 157-69.

[3] Devlin, J., \& Azhar, S. (2004). Life would be a lot easier if we were a Kit Kat': Practitioners' views on the challenges of branding financial services successfully. Journal of Brand Management. 12 (1), 12-30.

[4] Evans, M., Jamal A. \& Foxall, G. (2006), Consumer Behavior, Wiley, Chichester.

[5] Gabaix, X \& Laibson, D. (2004), "Competition and consumer confusion"' Harvard University, Department of Economics

[6] Jeremy, S. (2007). Ease the Confusion of Buying a Laptop With Several Easy Steps. Retrieved, 22 April 2010 at 
http://ezinearticles.com/?Ease-the-Confusion-of-Buying-a-LaptopWith-Several-Easy-Steps\&id=3124364.

[7] Mitchell, V. \& Papavassiliou (1997) "Exploring consumer confusion in the watch market", Marketing Intelligence \& Planning Journal, Vol. 15, Issue 4, pp. 164-172

[8] Mitchell, V. \& Papavassiliou (1999) "Marketing causes and implications of customer confusion", Journal of Product \& Brand Management, Vol. 8, Issue 4, pp. 319-339

[9] Nelson, W. (2002), "All Power to the Consumer? Complexity and Choice in Consumers' Lives", Journal of Consumer Behavior, 2(2), 185-195.

[10] Olshavsky, R.W. \& Granbois, D.H. (1979), “Consumer Decision Making - Fact of Fiction?", Journal of Consumer Research, 6 (September), 93-100.

[11] Solomon, M.R., (2009) Consumer Behavior, Buying, Having and Being, Pearson International Edition.

[12] Turnbull, P.W., Leek, S. \& Ying, G. (2000), "Customer Confusion: The Mobile Phone Market", Journal of Marketing Management, 16(1-3), 143-163.

[13] Zaltman, G. (2003), "How customers think, essential insights into the mind of the market", "what consumers can't tell you and competitors don't know", Harvard Business School Press

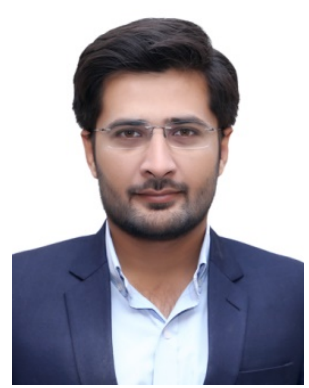

Muhammad Arsalan Khan is a researcher and lecturer who was born in Karachi, Pakistan on 2nd October 1990. He has completed his Bachelor in Business Administration from Iqra University, Karachi, Pakistan in year 2015. After that he has completed his Master's in Business Administration from Iqra University, Karachi, Pakistan in year 2017 and now he is enrolled in $\mathrm{PhD}$ program. He has more than three year of experience in corporate and currently working as a lecturer in Indus University, Karachi, Pakistan since February 2019. He has more than a year of working experience for higher education.

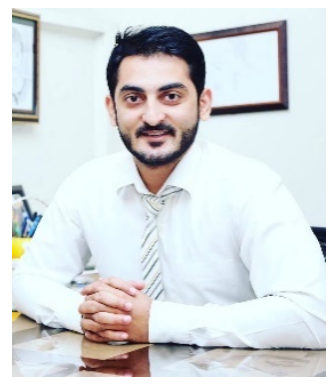

Muhammad Abdullah Idrees is a researcher and lecturer who was born in Jeddah, Saudi Arabia on 7th March 1991. He has completed his Bachelor's in Business Administration from Bahria University, Karachi, Pakistan in year 2014. After that he has completed his Master's in Business 7 Administration from SZABIST, Karachi, Pakistan in year 2016 and now he is enrolled in $\mathrm{PhD}$ program. He has more than one year of experience in corporate and currently working as a lecturer in faculty of Management Sciences at Indus University, Karachi, Pakistan since February 2016. He has more than 4 years of working experience for higher education.

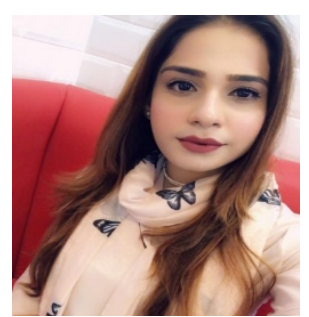

Ayesha Khan is a researcher and lecturer who was born in Islamabad on September 3, 1992. She completed her Bachelor's in Business Administration from Iqra University Karachi, Pakistan in 2016 followed by her Masters in Human Resource Management from same university in 2018. Starting her career as a human resource manager at a renowned pharmaceutical company for a year then left it for her passion which was teaching, and became member of the faculty of business management of same university she studied from. 